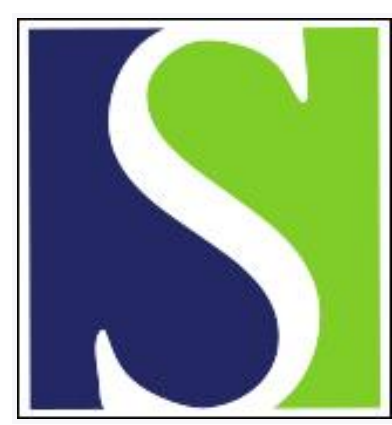

Scand J Work Environ Health 1997;23(5):351-358

https://doi.org/10.5271/sjweh.231

Issue date: Oct 1997

Respiratory symptoms, across-shift lung function changes and lifetime exposures of welders in New Zealand

by Fishwick D, Bradshaw LM, Slater T, Pearce N

Key terms: pulmonary function; welding fume

This article in PubMed: www.ncbi.nlm.nih.gov/pubmed/9403465

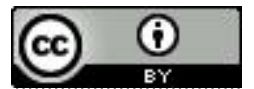




\title{
Respiratory symptoms, across-shift lung function changes and lifetime exposures of welders in New Zealand
}

\author{
by David Fishwick, MD, ${ }^{1}$ Lisa M Bradshaw, RGON, ${ }^{1}$ Tania Slater, ${ }^{1}$ Neil Pearce, PhD ${ }^{1}$
}

\begin{abstract}
Fishwick D, Bradshaw LM, Slater T, Pearce N. Respiratory symptoms, across-shift lung function changes and lifetime exposures of welders in New Zealand. Scand $J$ Work Environ Health 1997;23(5):351—8.

Objectives The possibility was investigated that exposure to welding fumes causes an acute decrease in pulmonary function.

Methods Changes in the pulmonary function of 62 current welders and 75 nonwelders at the same sites and the relationship with work-related symptoms were recorded.

Results Work-related cough was reported by $22.6 \%$ of the current welders and $6.7 \%$ of the nonwelders [odds ratio (OR) 4.1, 95\% confidence interval $(95 \% \mathrm{Cl}) 1.5-11.5$ ], and the respective figures for at least 1 workrelated symptom were $30.7 \%$ and $16.0 \%$ (OR 2.3, 95\% CI 1.0-5.2). The groups' preshift lung function did not differ. The mean percentage change from the base-line value of the forced expiratory volume in $1 \mathrm{~s}\left(\mathrm{FEV}_{10}\right)$ after 15 minutes of work was $-2.8 \%$ (range $-29.3 \%$ to $+20.9 \%$ ) for the current welders and $+1.0 \%$ (range $-20.7 \%$ to $+22.6 \%)$ for the nonwelders $(\mathrm{P}=0.01)$. A multivariate analysis identified current welding as the most significant risk factor for a decrease of at least $5 \%$ in $\mathrm{FEV}_{1.0}$ after 15 minutes, the risk being greater for those with no local exhaust ventilation (OR 22.4, 95\% CI 4.5-113.4) than for those with personal protection only (OR 16.0, $95 \% \mathrm{Cl} 2.1-122.9$ ) and those with local exhaust ventilation (OR 2.8, 95\% CI $0.2-41.2$ ) or passive exposure only (OR 2.0, $95 \%$ CI $0.5-8.8$ ).
\end{abstract}

Conclusions An acute decrease in $\mathrm{FEV}_{1.0}$ in relation to work is more prevalent among welders than among nonwelders, and is more common among welders without local exhaust ventilation than among those with it.

Key terms pulmonary function, welding fume.

Industrial welding leads to complex potential exposure to particulates and gases. Many of the components of welding products are likely to evoke a pulmonary response although the responses differ between workers and it is likely that many different mechanisms over differing time courses are responsible for the varied respiratory disorders that are known to occur with welding (1).

The spectrum of potential respiratory disorders related to welding is large, ranging from an acute response, such as metal fume fever (2), a well-described acute febrile illness normally related to the inhalation of zinc oxide, to much less common cases of hypersensitivity pneumonitis, related to a wide range of potential causes (1), to welding-related pneumoconiosis (3).

Although cases of occupational asthma in relation to exposure to welding fumes have been documented $(4,5)$ and the response to welding fumes in laboratory settings has also been described (6), very little is known about the acute pulmonary response to welding fumes in the workplace.

However, a recent New Zealand study on welders (7) (confined to nonsmokers) documented changes in peak expiratory flow (PEF) on the first workday, after exposure to welding products among a group of welders mainly using mild steel as the base metal. These changes did not occur in an unexposed comparison group. Similarly, another smaller study based in New Zealand (8) noted a particularly high level of respiratory symptoms in a group of welders. However, in neither study was an assessment made of the potential effects of cigarette smoking, either alone or in combination with welding fumes, on respiratory symptoms and the decline in lung function.

Our study of New Zealand welders was designed to assess the potential effects of welding fume exposure, work practices such as the use of respiratory protection

1 Wellington Asthma Research Group, Department of Medicine, Wellington School of Medicine, Wellington, New Zealand.

Address for correspondence: Dr David Fishwick, Wellington Asthma Research Group, Department of Medicine, Wellington School of Medicine, PO Box 7343, Wellington, New Zealand. [E-mail: warg.sec@wnmeds.ac.nz] 
and local exhaust facilities, previous lifetime exposure to welding products, and smoking on work-related respiratory symptoms and acute changes in respiratory function early in the workshift.

\section{Subjects and methods}

Eight New Zealand sites with regular welding in their industrial process were approached. All the current welders at each site and either all nonwelders or a subsample (at larger sites) were asked to take part in this study. The majority of the welders worked with mild steel (or in some cases with both mild steel and stainless steel) as a base metal and used either metal-inert gas (MIG) or tungsten-inert gas (TIG) techniques.

\section{Questionnaire}

The questionnaire included demographic data, current smoking habits, and questions about work-related respiratory symptoms and selected questions from the European Community Respiratory Health Survey (9). Reports of current or recent cough, phlegm, wheeze, chest tightness, and shortness of breath were recorded, along with whether these symptoms were related to work, the latter being defined as a symptom worse at work or improving on rest days)

\section{Current welding exposure}

The current job type and its duration was recorded, along with whether the worker was welding on the day of the study (current welders). The proportion of the day spent welding (and confined space welding) were noted in a manner similar to that of the study of Cotes et al (10). The type of current welding work and the work area was recorded for each person when appropriate so that the workers could be broadly stratified into the following 3 groups: (i) those currently welding on the study day, (ii) those not welding but experiencing passive exposure to welding fumes, and (iii) those not welding or working in an exposed environment. The use of any available respiratory protection and local exhaust ventilation adjacent to the site of the welding were also recorded.

\section{Previous welding exposure}

A series of questions was administered to estimate total lifetime exposure to the products of industrial welding, as some current nonwelders had had welding exposure in previous jobs. Workers were asked to describe their previous lifetime exposure in terms of sequential periods of time spent in differing jobs and the associated proportion of the day spent welding in each of them. The effective exposure in years (per job) was calculated as the product of these 2 variables, and the cumulative measure (ex- pressed in years) was calculated by summing all the individual exposures for each job. The resulting total has been subsequently referred to as the total exposure index.

\section{Exposure variables}

The total exposure index was ranked into 3 categories for the multivariate analysis. Similarly, the proportion of time currently spent welding in confined spaces was divided into 3 rankings. The current workplace information and use of exhaust ventilation were used to define the following 5 categories of current work practice: (i) not exposed: not welding on the study day and not exposed to welding; (ii) passive exposure only: not welding on the study day but exposed passively to welding; (iii) welding with local exhaust: welding on the study day and using local exhaust ventilation; (iv) welding, no exhaust, but personal protection used: welding on the study day, not using local exhaust but using respiratory protection while welding; and (v) welding, no exhaust and no personal protection: welding on the study day, using neither local exhaust nor respiratory protection while welding.

\section{Pulmonary function}

All the workers who completed the questionnaire were invited to undergo pulmonary function testing, performed using a calibrated portable spirometer (Alpha Spirometer, Vitalograph).

The measurements were taken before the shift (time 0 ), 15 minutes after the start of welding work (or at a corresponding time for workers not welding) and again at $7 \mathrm{~h}$ into the workshift. All the preshift values were recorded prior to any exposure to welding fumes on the study day and at least $16 \mathrm{~h}$ since any previous welding work. Forced expiratory volume in $1 \mathrm{~s}$ ( $\mathrm{FEV}_{1.0}$ in liters), forced vital capacity (FVC in liters), peak expiratory flow ( $\mathrm{PEF}$ in liters per minute) and forced expiratory flow rate at $25-75 \%$ of the FVC $\left(\mathrm{FEF}_{25-75}\right.$ in liters per minute) were measured, the best value of 3 forced expiratory maneuvers in the standing position being used. A small number of workers did not complete 3 measurements for reasons of work commitment, and these workers have been excluded from the analysis of lung function.

All variables were then converted either into the percentage of the predicted value for the person in question or the percentage change from the base-line value, the measurement at time 0 representing the base-line value.

In order to determine which factors were associated with an acute decrease in lung function, the workers with at least a $5 \%$ decrease in $\mathrm{FEV}_{1.0}$ at 15 minutes into the welding work or shift were grouped together in the multivariate analysis. This figure was chosen to allow comparison with the previous workplace study performed in New Zealand, and, while it does not reflect a larger change normally considered diagnostic of asthma (for 
example, between $15 \%-20 \%$ ), it represents an intuitively reasonable cutoff for further investigation.

\section{Data analysis}

The statistical analysis system (11) was used for all the analyses. Continuous variables were compared between the groups by estimating the mean and standard deviation. Prevalence odds ratios were calculated using the Mantel-Haenszel method (12).

Logistic regression was performed to calculate adjusted odds ratios [adjusted for age, gender and smoking (current, former, never smoker) and the other risk factors in the model] for each risk factor.

All the workers in this study gave written informed consent to take part, and the study was approved by the Wellington Ethics Committee.

\section{Results}

Table 1 shows the demographic details and smoking category of the 137 workers who took part in the study; 7 workers declined to participate in the study, resulting in an overall response rate of $95.1 \%$. Sixty-two workers (45.3\% of the study population) performed a weld on the study day ("current welders"). Current welders did not differ significantly from the 75 nonwelders in terms of their ethnicity, smoking habits, and years of work experience. However, the current welders were younger [mean age 36.9 (SD 11.1) years] than the nonwelders [mean age 40.3 (SD 13.6) years] and, as might be anticipated, had a significantly greater mean lifetime exposure index [mean 7.7 (SD 6.7) years] in comparison with the nonwelders [mean 2.3 (SD 4.4) years]. Eighty-nine (65\%) workers did not normally use respiratory protection of any form while welding, and only 10 workers (16.1\% of the current welders) welded with functioning local exhaust ventilation.

Table 2 shows the differences in the symptom prevalences between the current welders and nonwelders. The current welders complained of significantly more workrelated cough (OR 4.1, 95\% CI 1.5-11.5) and other work-related symptoms than the nonwelders did. The report of at least 1 work-related symptom was significantly more common among the current welders (OR 2.3, 95\% CI 1.0-5.2). Fifteen current welders (24\%) reported at least 1 episode of metal-fume fever.

Table 1. Characteristics of the participants by factory site.

\begin{tabular}{|c|c|c|c|c|c|c|c|c|}
\hline \multirow[t]{2}{*}{ Factory } & \multirow[t]{2}{*}{$N$} & \multirow{2}{*}{$\begin{array}{c}\text { Male } \\
(\%)\end{array}$} & \multirow{2}{*}{$\begin{array}{c}\text { Mean } \\
\text { age } \\
\text { (years) }\end{array}$} & \multicolumn{3}{|c|}{ Smoking } & \multicolumn{2}{|c|}{ Ethnicity } \\
\hline & & & & $\begin{array}{c}\text { Current } \\
\text { smokers } \\
(\%)\end{array}$ & $\begin{array}{c}\text { Ex- } \\
\text { smokers } \\
(\%)\end{array}$ & $\begin{array}{c}\text { Never } \\
\text { smokers } \\
(\%)\end{array}$ & $\begin{array}{c}\text { Polynesian } \\
(\%)\end{array}$ & $\begin{array}{c}\text { Other } \\
(\%)\end{array}$ \\
\hline $\begin{array}{l}1 \\
2 \\
3 \\
4 \\
5 \\
6 \\
7 \\
8\end{array}$ & $\begin{array}{r}27 \\
13 \\
8 \\
17 \\
10 \\
29 \\
15 \\
18\end{array}$ & $\begin{array}{c}100 \\
100 \\
100 \\
100 \\
100 \\
100 \\
66.7 \\
94.4\end{array}$ & $\begin{array}{l}40.9 \\
38.5 \\
35.0 \\
42.2 \\
34.8 \\
38.4 \\
32.1 \\
42.7\end{array}$ & $\begin{array}{r}33.3 \\
7.7 \\
37.5 \\
52.9 \\
40.0 \\
65.5 \\
53.3 \\
27.8\end{array}$ & $\begin{array}{r}29.6 \\
30.8 \\
25.0 \\
0.0 \\
30.0 \\
17.2 \\
6.7 \\
33.3\end{array}$ & $\begin{array}{l}37.0 \\
61.5 \\
37.5 \\
47.1 \\
30.0 \\
17.2 \\
40.0 \\
38.9\end{array}$ & $\begin{array}{r}7.4 \\
0.0 \\
62.5 \\
70.6 \\
10.0 \\
6.9 \\
66.7 \\
16.7\end{array}$ & $\begin{array}{r}92.6 \\
100.0 \\
37.5 \\
29.4 \\
90.0 \\
93.1 \\
33.3 \\
83.3\end{array}$ \\
\hline Total & 137 & 95.6 & 38.8 & 42.3 & 21.2 & 36.5 & 25.5 & 74.5 \\
\hline
\end{tabular}

Table 2. Respiratory symptoms by welding exposure category. (OR $=$ odds ratio, $95 \% \mathrm{Cl}=95 \%$ confidence interval)

\begin{tabular}{|c|c|c|c|c|c|c|}
\hline \multirow[t]{2}{*}{ Symptom } & \multicolumn{2}{|c|}{$\begin{array}{l}\text { Symptoms in current } \\
\text { welders }(N=62)\end{array}$} & \multicolumn{2}{|c|}{$\begin{array}{l}\text { Symptoms in current } \\
\text { nonwelders }(N=75)\end{array}$} & \multirow[t]{2}{*}{$\mathrm{OR}$} & \multirow[t]{2}{*}{$95 \% \mathrm{Cl}$} \\
\hline & $N$ & $\%$ & $N$ & $\%$ & & \\
\hline Chronic bronchitis & 9 & 14.5 & 4 & 5.3 & 3.0 & $0.9-9.9$ \\
\hline Persistent cough & 18 & 29.0 & 14 & 18.7 & 1.8 & $0.8-4.0$ \\
\hline Work-related cough & 14 & 22.6 & 5 & 6.7 & 4.1 & $1.5-11.5$ \\
\hline Any chest tightness & 9 & 14.5 & 11 & 14.7 & 1.0 & $0.4-2.6$ \\
\hline Chest tightness just with colds & 13 & 21 & 16 & 21.3 & 1.0 & $0.4-2.2$ \\
\hline Work-related chest tightness & 5 & 8.1 & 3 & 4.0 & 2.1 & $0.5-9.0$ \\
\hline Wheeze or whistle in the last 12 months & 32 & 51.6 & 28 & 37.3 & 1.8 & $0.9-3.6$ \\
\hline Wheeze just with colds & 20 & 32.3 & 27 & 36.0 & 0.9 & $0.4-1.7$ \\
\hline Work-related wheeze & 9 & 14.5 & 5 & 6.7 & 2.4 & $0.8-7.4$ \\
\hline Shortness of breath, grade one & 2 & 3.2 & 5 & 6.7 & 0.5 & $0.1-2.4$ \\
\hline Work-related shortness of breath & 1 & 1.6 & 3 & 4.0 & 0.4 & $0.04-3.6$ \\
\hline Any work-related symptoma & 19 & 30.7 & 12 & 16.0 & 2.3 & $1.0-5.2$ \\
\hline
\end{tabular}

a Any of work-related cough, chest tightness, wheeze or shortness of breath. 
Table 3 summarizes the pulmonary function measurements taken on the study day and is based on complete data from 132 workers $(96.4 \%$ of all the workers in the study). The base-line, preshift percentage of the predicted lung function did not differ significantly between the current welders and the nonwelders: preshift $\mathrm{FEV}_{1.0}$ mean 101.1 (SD 16.7) and 104.0 (SD 14.1), FVC mean 109.5 (SD 14.9) and 111.4 (SD 16.2), PEF mean 91.7 (SD 21.5) and 92.5 (SD 21.8), and $\mathrm{FEF}_{25-75}$ mean 76.5 (SD 24.0) and 78.7 (SD 24.1), respectively.

All the data in table 3 relate to the mean percentage of change from the base-line value recorded immediately prior to the welding. The change after 15 minutes and after $7 \mathrm{~h}$ is shown along with the mean of the maximum change in these 2 recordings for each worker.

The mean decrease in $\mathrm{FEV}_{1.0}$ after 15 minutes of welding was 2.8 (range -29.3 to +20.9 )\% in comparison with a slight increase among the nonwelders [mean 1.0 (range -20.7 to +22.6 ) \%]. These small differences were significant for changes after 15 minutes of welding and the maximum decrease on the study day. The mean fall for smoking welders was $3.7 \%$ in comparison with $2.1 \%$ for the nonsmoking welders. Similarly, smoking non- welders showed an increase of $1.4 \%$ in comparison with an increase of $0.7 \%$ for the nonsmoking nonwelders.

The relatively small mean change in $\mathrm{FEV}_{1.0}$ somewhat hides the pronounced decrease in certain workers in the current welding subgroup. For example, 21 current welders had a decrease in lung function of at least $5 \%$ after 15 minutes of welding and, of these, 12 sustained a decrease of greater than $10 \%$ and 7 had a decrease greater than $15 \%$. Declines in $\mathrm{FEV}_{1.0}$ were correspondingly less common within the nonwelding group; 12 workers showing a decrease of at least $5 \%, 5$ a decrease of at least $10 \%$, and 1 a decrease greater than $15 \%$.

Table 4 illustrates the general lack of relationship between reported respiratory symptoms and the documented decrease in $\mathrm{FEV}_{1.0}$ on the same day, although work-related chest tightness did show a marked association with the decrease in lung function after 15 minutes into the shift. The report of any work-related respiratory symptom was more prevalent $(36.4 \%)$ among the nonsmoking welders than among the smoking welders $(24.1 \%)$, and, for the nonwelders, work-related symptoms were more prevalent among the smokers $(27.6 \%)$ than among the nonsmokers $(8.7 \%)$.

Table 3. Mean percentage of change from the preexposure base-line values of the forced expiratory volume in $1 \mathrm{~s}\left(\mathrm{FEV} V_{1.0}\right)$, peak expiratory flow (PEF) and forced expiratory flow rate at $25 \%-75 \%$ of forced vital capacity $\left(\mathrm{FEF}_{25-75}\right)$ after 15 minutes of welding and after $7 \mathrm{~h}$ of work and also the maximum decrease for current welders and nonwelders.

\begin{tabular}{|c|c|c|c|c|c|c|}
\hline \multirow[t]{2}{*}{ Group } & \multicolumn{2}{|r|}{$\mathrm{FEV}_{1.0}$} & \multicolumn{2}{|r|}{ PEF } & \multicolumn{2}{|c|}{$\mathrm{FEF}_{25-75}$} \\
\hline & Mean \% & $\mathrm{SD}$ & Mean $\%$ & $\mathrm{SD}$ & Mean \% & SD \\
\hline \multicolumn{7}{|l|}{ Current welders } \\
\hline \multicolumn{7}{|l|}{ After $15 \mathrm{~min}$} \\
\hline \multicolumn{7}{|l|}{ Site } \\
\hline 1 & -3.0 & 9.9 & .. &.. &.. & .. \\
\hline 2 & +2.1 & 1.5 & .. &.. &.$\cdot$ & .. \\
\hline 3 & -0.1 & 2.8 & .. & .. & .. &.. \\
\hline 4 & -9.0 & 5.1 & .. & .. & .. &.. \\
\hline 5 & -6.0 & 9.7 & .. & .. &.. &.. \\
\hline 6 & -5.4 & 13.3 & .. & .. & .. & .. \\
\hline 7 & +1.9 & 12.2 & .. & .. & .. &.. \\
\hline 8 & +2.2 & 5.9 &.. & .. &.. & " \\
\hline All & -2.8 & $9.8\left(P<0.01^{a}\right)$ & -1.9 & $19.3\left(P<0.29^{\mathrm{a}}\right)$ & -2.9 & $19.2\left(P<0.04^{a}\right)$ \\
\hline \multicolumn{7}{|l|}{ Local exhaust } \\
\hline Yes & +3.9 & 8.8 & .. &.. &.. & .. \\
\hline No & -4.3 & 9.4 & $\cdot \cdot$ & .. & $\cdot$. & .. \\
\hline After $7 \mathrm{~h}$ & -1.2 & $10.2\left(P<0.14^{a}\right)$ & +1.7 & $22.9\left(\mathrm{P}<0.42^{\mathrm{a}}\right)$ & -2.5 & $22.1\left(\mathrm{P}<0.01^{\mathrm{a}}\right)$ \\
\hline Maximum decrease & -6.5 & $9.4\left(P<0.03^{a}\right)$ & -8.2 & $17.4\left(\mathrm{P}<0.32^{\mathrm{a}}\right)$ & -9.7 & $20.0\left(P<0.02^{a}\right)$ \\
\hline \multicolumn{7}{|l|}{ Current nonwelders } \\
\hline \multicolumn{7}{|l|}{ After $15 \mathrm{~min}$} \\
\hline \multicolumn{7}{|l|}{ Site } \\
\hline 1 & -4.8 & 5.9 & .. & .. & .. &.. \\
\hline 2 & +3.4 & 6.8 & .. & .. &.. &.. \\
\hline 3 & -3.4 & 3.0 & .. &.. &.. & .. \\
\hline 4 & +2.5 & 3.6 & .. & .. & .. & .. \\
\hline 5 & +0.7 & 5.3 &.. & .. &.$\cdot$ &.. \\
\hline 6 & +2.3 & 9.1 & .. & .' & .. & .. \\
\hline 7 & -0.7 & 5.2 & .. & .. & .. &.. \\
\hline 8 & +5.5 & 3.2 &.. & .. &. & .. \\
\hline All & +1.0 & 6.9 & 1.6 & 17.4 & +5.3 & 23.3 \\
\hline After $7 \mathrm{~h}$ & +1.7 & 10.8 & +5.3 & 25.8 & +7.7 & 22.0 \\
\hline Maximum decrease & -3.0 & 7.9 & -5.2 & 15.7 & -1.0 & 19.1 \\
\hline
\end{tabular}

a Versus corresponding values of current nonwelders. 
Table 4. Relationship between various respiratory symptoms and the change in lung function after 15 minutes of work. (FEV $V_{1.0}=$ forced expiratory volume in $1 \mathrm{~s}, \mathrm{OR}=$ odds ratio, $95 \% \mathrm{Cl}=95 \%$ confidence interval)

\begin{tabular}{|c|c|c|c|c|c|c|}
\hline \multirow[t]{2}{*}{ Symptom } & \multicolumn{2}{|c|}{$\begin{array}{l}\text { Symptoms in workers with } \\
\text { a FEV } \\
\text { than or decrease greater } \\
15 \text { minutes of work } \\
(\mathbb{N}=33)\end{array}$} & \multicolumn{2}{|c|}{$\begin{array}{l}\text { Symptoms in workers with } \\
\text { a FEV } 10 \text { decrease of less } \\
\text { than } 5 \% \text { after } 15 \text { minutes } \\
\text { of work }(\mathrm{N}=94)\end{array}$} & \multirow[t]{2}{*}{$\mathrm{OR}$} & \multirow[t]{2}{*}{$95 \% \mathrm{Cl}$} \\
\hline & N & $\%$ & N & $\%$ & & \\
\hline \multicolumn{7}{|c|}{ Self-reported asthma } \\
\hline $\begin{array}{l}\text { Yes } \\
\text { No }\end{array}$ & $\begin{array}{r}3 \\
30\end{array}$ & $\begin{array}{l}25.0 \\
26.1\end{array}$ & $\begin{array}{c}9 \\
85\end{array}$ & $\begin{array}{l}75.0 \\
73.9\end{array}$ & 0.9 & $0.2-3.7$ \\
\hline \multicolumn{7}{|c|}{ Work-related cough } \\
\hline $\begin{array}{l}\text { Yes } \\
\text { No }\end{array}$ & $\begin{array}{r}3 \\
30\end{array}$ & $\begin{array}{l}16.7 \\
27.5\end{array}$ & $\begin{array}{l}15 \\
79\end{array}$ & $\begin{array}{l}83.3 \\
72.5\end{array}$ & 0.5 & $0.1-1.9$ \\
\hline \multicolumn{7}{|c|}{ Work-related wheeze } \\
\hline $\begin{array}{l}\text { Yes } \\
\text { No }\end{array}$ & $\begin{array}{r}5 \\
28\end{array}$ & $\begin{array}{l}38.5 \\
24.6\end{array}$ & $\begin{array}{r}8 \\
86\end{array}$ & $\begin{array}{l}61.5 \\
75.4\end{array}$ & 1.9 & $0.6-6.3$ \\
\hline \multicolumn{7}{|c|}{ Work-related chest tightness } \\
\hline $\begin{array}{l}\text { Yes } \\
\text { No }\end{array}$ & $\begin{array}{r}5 \\
28\end{array}$ & $\begin{array}{l}62.5 \\
23.5\end{array}$ & $\begin{array}{r}3 \\
91\end{array}$ & $\begin{array}{l}37.5 \\
76.5\end{array}$ & 5.4 & $1.4-21.3$ \\
\hline \multicolumn{7}{|c|}{ Any work-related symptoma } \\
\hline $\begin{array}{l}\text { Yes } \\
\text { No }\end{array}$ & $\begin{array}{l}10 \\
23\end{array}$ & $\begin{array}{l}33.3 \\
23.7\end{array}$ & $\begin{array}{l}20 \\
74\end{array}$ & $\begin{array}{l}66.7 \\
76.3\end{array}$ & 1.6 & $0.7-3.9$ \\
\hline
\end{tabular}

a Any of work-related cough, chest tightness, wheeze or shortness of breath.

Table 5 shows the results of the multivariate analysis for the defined $5 \%$ decrease in $\mathrm{FEV}_{1.0}$ at 15 minutes into the shift. This decrease was found to be associated, after correction for age, ethnicity, smoking habits and basal lung function, with both categories of welding practice not involving the use of local exhaust ventilation.

\section{Discussion}

This study found an acute decrease in lung function in the early part of the workshift among a group of welders currently exposed predominantly to the products of MIG and TIG welding. The analysis was repeated to assess individual welding types within the population, and the results did not differ markedly from those presented for the overall group. Similarly, at 1 site (site 6), welding was done on stainless steel although no significant differences were found between the outcome measures used in this study and the type of base metal. Although it is likely that those welding on stainless steel have differing exposures, including chromium and nickel, we are not able to comment further on this point.

The absolute decrease in $\mathrm{FEV}_{1.0}$ documented in this study was relatively small. However, it was unlikely to be related to spontaneous fluctuations in $\mathrm{FEV}_{1.0}$ throughout the day, as the $\mathrm{FEV}_{1.0}$ of the nonwelders was found to rise at 15 minutes into the same workshift. Furthermore, as all these workshifts started early in the morning, one might expect the $\mathrm{FEV}_{1.0}$ to have a small drift upwards, even in normal persons, and therefore an absolute de- crease at this time of day seems even more clinically significant. Furthermore, 8 workers $(6.1 \%)$ showed a decline that was greater than $15 \%$. There was an unexplained reduction in the mean base-line percentage of the predicted $\mathrm{FEF}_{25-75}$ although a reduction in forced expiratory flow values has been noted previously in a population of manual arc welders (13) and also among welders working with mild steel (14).

The PEF was solely used to assess the acute airway response to welding fumes in the most recent study of New Zealand welders (7), and it showed a drop of approximately $5 \%$ after 15 minutes of welding in work practices similar to the ones done in the current study. If our study had used this method of assessment alone, the work-related effect on the welders would not have been identified.

The timing of measurements through the shift also appeared crucial to the findings of this study. We chose to measure the first exposure effect at 15 minutes into the shift because of the work performed by Donaghue et al (7) and because it seemed plausible that such an immediate effect could occur. For example, very early changes in lung function after exposure to the products of welding have been documented for 1 gas arc welder with a diagnosis of occupational asthma (5). The decline in $\mathrm{FEV}_{1.0}$ after 15 minutes of welding work had largely resolved at 7 hours into the shift in our study, although the mean base-line value had not yet been attained. Although this study is perhaps too small to comment on the changes in pulmonary function accurately over welding time, it does suggest that studies concentrating on measuring lung function across a shift may not show a rele- 
Table 5. Factors associated with a greater than $5 \%$ fall in forced expiratory volume in $1 \mathrm{~s}\left(\mathrm{FEV}_{1,0}\right)$ after 15 minutes of work. (OR $=$ odds ratio, $95 \% \mathrm{Cl}=95 \%$ confidence interval)

\begin{tabular}{|c|c|c|c|c|c|c|}
\hline Associated factor & $\begin{array}{l}\text { Workers with } \\
\text { FEV }_{1.0} \text { decrease } \\
\text { greater than } \\
\text { or equal to } 5 \% \\
\text { after } 15 \text { minutes } \\
\text { of work } \\
(N=33)\end{array}$ & $\begin{array}{c}\text { Workers } \\
\text { with FEV } \mathrm{F}_{10} \\
\text { decrease of Jess } \\
\text { than } 5 \% \text { after } \\
15 \text { minutes } \\
\text { of work } \\
(\mathrm{N}=95)\end{array}$ & OR & $95 \% \mathrm{Cl}$ & Adjusted OR & $\begin{array}{l}95 \% \mathrm{Cl} \\
\text { of the } \\
\text { adjusted } \\
\text { OR }\end{array}$ \\
\hline \multicolumn{7}{|l|}{ Smoking } \\
\hline $\begin{array}{l}\text { Never smoker } \\
\text { Ex-smoker } \\
\text { Current smoker }\end{array}$ & $\begin{array}{r}11 \\
6 \\
16\end{array}$ & $\begin{array}{l}35 \\
21 \\
39\end{array}$ & $\begin{array}{l}1.0 \\
0.9 \\
1.3\end{array}$ & $\begin{array}{l}0.3-2.8 \\
0.5-3.2\end{array}$ & $\begin{array}{l}1.0 \\
1.1 \\
0.9\end{array}$ & $\begin{array}{l}0.3-4.8 \\
0.3-2.9\end{array}$ \\
\hline \multicolumn{7}{|l|}{ Ethnicity } \\
\hline $\begin{array}{l}\text { Other } \\
\text { Polynesian }\end{array}$ & $\begin{array}{l}23 \\
10\end{array}$ & $\begin{array}{l}73 \\
22\end{array}$ & $\begin{array}{l}1.0 \\
1.4\end{array}$ & $0.6-3.5$ & $\begin{array}{l}1.0 \\
2.8\end{array}$ & $0.9-9.2$ \\
\hline \multicolumn{7}{|l|}{ Age (years) } \\
\hline $\begin{array}{l}17-24 \\
25-40 \\
>40\end{array}$ & $\begin{array}{r}4 \\
15 \\
14\end{array}$ & $\begin{array}{l}11 \\
41 \\
43\end{array}$ & $\begin{array}{l}1.0 \\
1.0 \\
0.9\end{array}$ & $\begin{array}{l}0.3-3.7 \\
0.3-3.2\end{array}$ & $\begin{array}{l}1.0 \\
0.7 \\
0.9\end{array}$ & $\begin{array}{l}0.1-3.6 \\
0.2-5.2\end{array}$ \\
\hline \multicolumn{7}{|l|}{ Percentage of predicted $\mathrm{FEV}_{1.0}$} \\
\hline $\begin{array}{l}\geq 100 \\
<100\end{array}$ & $\begin{array}{l}16 \\
17\end{array}$ & $\begin{array}{l}54 \\
41\end{array}$ & $\begin{array}{l}1.0 \\
1.4\end{array}$ & $0.6-3.1$ & $\begin{array}{l}1.0 \\
1.0\end{array}$ & $0.3-2.7$ \\
\hline \multicolumn{7}{|c|}{$\begin{array}{l}\text { Percentage of time spent currently } \\
\text { welding in confined spaces }\end{array}$} \\
\hline $\begin{array}{l}0-2 \\
2-10 \\
>10\end{array}$ & $\begin{array}{r}23 \\
4 \\
6\end{array}$ & $\begin{array}{l}67 \\
11 \\
17\end{array}$ & $\begin{array}{l}1.0 \\
1.1 \\
1.0\end{array}$ & $\begin{array}{l}0.3-3.7 \\
0.4-2.9\end{array}$ & $\begin{array}{l}1.0 \\
0.8 \\
0.5\end{array}$ & $\begin{array}{l}0.1-4.3 \\
0.1-2.0\end{array}$ \\
\hline \multicolumn{7}{|l|}{ Total exposure index (years) } \\
\hline $\begin{array}{l}0-4 \\
4-10 \\
>10\end{array}$ & $\begin{array}{r}24 \\
1 \\
8\end{array}$ & $\begin{array}{l}55 \\
26 \\
14\end{array}$ & $\begin{array}{l}1.0 \\
0.1 \\
1.3\end{array}$ & $\begin{array}{r}0.01-0.7 \\
0.5-3.5\end{array}$ & $\begin{array}{l}1.0 \\
0.04 \\
0.3\end{array}$ & $\begin{array}{l}0.0-0.4 \\
0.1-1.5\end{array}$ \\
\hline \multicolumn{7}{|l|}{ Current welding category } \\
\hline $\begin{array}{l}\text { Not exposed } \\
\text { Passive exposure only } \\
\text { Local exhaust' } \\
\text { No exhaust, protectionc } \\
\text { No exhaust, no protectionc }\end{array}$ & $\begin{array}{r}4 \\
6 \\
1 \\
6 \\
16\end{array}$ & $\begin{array}{r}29 \\
26 \\
9 \\
15 \\
16\end{array}$ & $\begin{array}{l}1.0 \\
1.7 \\
0.8 \\
2.9 \\
7.3\end{array}$ & $\begin{array}{l}0.4-6.6 \\
0.1-8.2 \\
0.7-11.9 \\
2.1-25.5\end{array}$ & $\begin{array}{r}1.0 \\
2.0 \\
2.8 \\
16.0 \\
22.4\end{array}$ & $\begin{array}{l}0.5-8.8 \\
0.2-41.2 \\
2.1-122.9 \\
4.5-113.4\end{array}$ \\
\hline
\end{tabular}

a Adjusted for other factors listed in the table.

- Exhaust implies local functioning extraction ventilation adjacent to the welding site.

c Protection implies normal use of a face mask or other personal protective device for welding tasks.

vant decrease if a very early assessment of lung function is not included.

Work-related symptoms were common in this study population, and work-related cough was found to be more frequent among the current welders than among the nonwelders. Although still a matter of controversy, chronic bronchitis is known to be associated with occupations involving exposure to dusts (15), and many studies have clearly documented an excess of these symptoms for current welders $(13,14,16-20)$ and sheet metal workers exposed to welding fumes (21).

The absolute levels of wheezing in the previous 12 months were high, and they were greater for the current welders $(51.6 \%)$ than for the nonwelders $(37.3 \%)$ when compared with the expected prevalence of about $24 \%$ for this age group in New Zealand (22).

If we assume that an acute work-related decrease in $\mathrm{FEV}_{1.0}$ is likely to be an important mark of an asthmatic (23) or irritant airway response to the products of welding fumes, it is vital to know if this decline leads to the development of work-related symptoms, if it is a consequence of these symptoms, or if the 2 processes occur independently with separate underlying mechanisms. This cross-sectional study can only supply limited insight in this respect, as it is likely that workers developing symptoms due to welding fumes either leave the work area, or at least change tasks, if possible, to reduce exposure and the results are relatively dependent on the "healthy worker" effect.

The type of fall observed in this study is also known to occur in exercise-induced asthma shortly after the onset of exercise (24).

The findings for workers without symptoms suggestive of asthma are particularly intriguing and of considerable interest. The lack of a relationship between a decline in $\mathrm{FEV}_{1.0}$ and respiratory symptoms, however, does stress the important practical point that workers with no respiratory symptoms (or at least no work-related symptoms) may be at risk of, or are actually experiencing, an early decline in work-related lung function. Even in our 
study, for example, 8 of the 12 welders with a decrease of at least $10 \%$ in $\mathrm{FEV}_{1.0}$ after 15 minutes of welding had no work-related symptoms. This finding has obvious implications for future questionnaire surveillance of similar work forces.

In the multivariate analysis, the overwhelming factor found to be associated with a decrease in lung function was work practice. In a comparison with workers totally unexposed to the products of welding workers, welding without local exhaust ventilation, regardless of the use of available respiratory protection, showed a strong association between this variable and a decrease in $\mathrm{FEV}_{1.0}$ at 15 minutes into the shift. Interestingly, the workers with passive workplace exposure had an increased risk for this decrease (OR 2.0) even though the difference was not statistically significant.

There is no current work that allows us to interpret these findings longitudinally for welders, although evidence is emerging from other occupational studies to suggest that acute responses to inhaled agents at work may be the precursor of chronic airway disease. It may well be that early changes in lung function across a workshift, perhaps potentiated by repeated exposure to a sensitizing agent and leading to bronchial hyperresponsiveness, may be partly responsible for longer term lung sequelae. Glindmeyer et al (25) found that an acrossshift decline in lung function was related to a chronic level of lung function loss in a prospective study of American cotton workers, a group of workers known to develop bronchial hyperresponsiveness in association with cotton dust exposure (26). Similarly, there are data relating an acute decline in lung function in association with work to subsequent chronic lung function loss in grain workers $(27,28)$ and also bronchial hyperresponsiveness and chronic lung function loss in other occupational groups in association with dust exposure (29).

To date, however, little is known about the relationship between exposure to welding fumes and bronchial hyperresponsiveness, although 1 study (18) did not show differences in the level of bronchial hyperresponsiveness between groups of current welders, although a surprisingly large number ( 46 of 77 ) sustained a decline of at least $20 \%$ in $\mathrm{FEV}_{1.0}$ after provocation with methacholine. Similarly, there is evidence to support the presence of bronchial hyperresponsiveness in aluminum and stainless steel welders (30) and shipyard arc welders (31).

In an impressive longitudinal study in the United Kingdom, Chinn et al (20) concluded that the correct use of locally directed exhaust ventilation reduces the annual decline in $\mathrm{FEV}_{1.0}$ seen in shipyard welders over 4 years. Although this longitudinal study and the current study are inherently different, it is perhaps tempting to postulate that current workers with large acute decreases in $\mathrm{FEV}_{1.0}$ in relation to not using local exhaust ventilation may be the group more at risk of future chronic lung impairment in association with welding fume exposure.

In summary, this study has documented work-related changes in $\mathrm{FEV}_{1.0}$ in a group of current welders and marked drops in $\mathrm{FEV}_{1.0}$ without symptoms in some welders. In addition, there were generally high levels of respiratory symptoms. Working without local extraction ventilation appeared to be the most important factor in determining the decrease in $\mathrm{FEV}_{1.0}$

\section{Acknowledgments}

The Wellington Asthma Research Group is funded by a Core Programme Grant, and this study was funded by a project grant from the Health Research Council of New Zealand. Dr David Fishwick received support from the Northern Regional Health Authority of the United Kingdom. There are no conflicts of interest to the publication of this paper.

We wish to thank Hazel Armstrong of the New Zealand Engineers Union, and the management, Union delegates, and workers who participated in, or assisted with, the study.

\section{References}

1. Sferlazza $S$, Beckett $W$. The respiratory health of welders. Am Rev Respir Dis 1991;143:1134—48.

2. Ross D. Welders metal fume fever. J Soc Occup Med 1974; 24:125-9.

3. Attield M, Ross D. Radiological abnormalities in electric arc welders. Br J Ind Med 1978;35:117-22.

4. Keskinen G, Kalliomäki P, Alanko K. Occupational asthma due to stainless steel welding fumes. Clin Allergy 1980;10: $151-9$.

5. Vandenplas O, Dargent F, Auverdin J-J, Boulanger J, Bossiroy J-M, Roosels D, et al. Occupational asthma due to gas metal arc welding on mild steel. Thorax 1995;50:587-8.

6. Francis T. A study of the immediate effects of welding fume on pulmonary function. J R Nav Med Serv 1982;68:136—44.

7. Donoghue A, Glass WI, Herbison G. Transient changes in pulmonary function of welders: a cross sectional study of Monday peak expiratory flow. Occup Environ Med 1994;51: $553-6$.

8. Dryson E, Rogers D. Exposure to fumes in typical New Zealand welding operations. NZ Med J 1991;104:365-7.

9. Burney P, Luczynska C, Chinn S, Jarvis D. The European Community respiratory health survey. Eur Respir J 1994;7: 954-60.

10. Cotes J, Feinmann E, Male V, Rennie F, Wickham C. Respiratory symptoms and impairment in shipyard welders and caulker/burners. Br J Ind Med 1989;46:292-301.

11. SAS institute. SAS language guide for personal computers. Carey (NC): SAS Institute, 1988.

12. Mantel N, Haenszel W. Statistical aspects of the analysis of data from retrospective studies of disease. JNCI 1959;22: $719-48$. 
13. Ozdemir O, Numanoglu N, Gonullu U, Savas I, Alper D, Gurses $\mathrm{H}$. Chronic effects of welding exposure on pulmonary function tests and respiratory symptoms. Occup Environ Med 1995;52:800-3.

14. Keimig D, Pomrehn P, Burmeister L. Respiratory symptoms and pulmonary function in welders of mild steel: a crosssectional study. Am J Ind Med 1983;4(4):489-99.

15. Becklake M. Chronic airflow limitation: its relationship to work in dusty occupations. Chest 1988:4:608-17.

16. Hayden S, Pincock A, Hayden J, Tyler L, Cross K, Bishop J. Respiratory symptoms and pulmonary function of welders in the engineering industry. Thorax 1984;39(6):442-7.

17. Sjögren B, Ulfvarson U. Respiratory symptoms and pulmonary function among welders working with aluminum, stainless steel and railroad tracks. Scand J Work Environ Health 1985; 11(1):27-32.

18. Wang Z, Larsson K, Malmberg P, Sjögren B, Hallberg B, Wrangskog $\mathrm{K}$. Asthma, lung function and bronchial responsiveness in welders. Am J Ind Med 1994;26:741 — 54.

19. Oxhoj H, Bake B, Wedel H, Wilhelmsen L. Effects of electric arc welding on ventilatory function. Arch Environ Health 1979:211-7.

20. Chinn D, Cotes J, Gamal FE, Wollaston J. Respiratory health of young shipyard welders and other tradesmen studied cross sectionally and longitudinally. Occup Environ Med 1995;55: $33-42$.

21. Hunting $\mathrm{K}$, Welch L. Occupational exposure to dust and lung disease among sheet metal workers. Br J Ind Med 1993;50: $432-42$.

22. Crane J, Lewis S, Slater T, Crossland L, Robson B, D'Souza $W$, et al. The self reported prevalence of asthma symptoms amongst adult New Zealanders. NZ Med J 1994;107(988):417-21.
23. Bright $\mathrm{P}$, Burge PS. The diagnosis of occupational asthma from serial measurements of lung function at and away from work. Thorax 1996;51:857-63.

24. Godfrey S, Silverman M, Anderson SD. Problems of interpreting exercise induced asthma. J Allergy Clin Immunol 1973;52:199.

25. Glindmeyer H, Lefante J, Jones R, Rando R, Weil H. Cotton dust and across shift change in FEV ${ }_{1}$ as predictors of annual change in FEV. . Am J Respir Crit Care Med 1994;149:58490 .

26. Fishwick D, Fletcher A, Pickering C, Niven R, Faragher E, Lung function, bronchial reactivity, atopic status and dust exposure in Lancashire cotton mill operatives. Am Rev Respir Dis 1992;145:1103-8.

27. Becklake M. Relationship of acute obstructive airway change to chronic (fixed) obstruction. Thorax 1995;50 suppl 1:51621.

28. Corey P, Hutcheon M, Broder I, Mintz S. Grain elevator workers show work-related pulmonary function changes and dose-effect relationships with dust exposure. $\mathrm{Br} \mathbf{J}$ Ind Med 1982;39:330-7.

29. Cowie R. Pulmonary dysfunction in gold miners with reactive airways. Br J Ind Med 1989;46:873 -6.

30. Nielsen J, Dahlquist M, Welinder H, Thomassen Y, Alexandersson R, Skerfving $\mathrm{S}$. Small airway function in aluminum and stainless steel welders. Int Arch Occup Environ Health 1993;65:101-5.

31. Hjortsberg U, Orbaek P, Arborelius M. Small airways dysfunction among non-smoking shipyard welders. $\mathrm{Br} J$ Ind Med 1992;49: 441-4.

Received for publication: 5 December 1996 